\title{
Tramos de historia colectiva Reseña Muestra Fotográfica «Agua de Nadie»
}

\author{
Liliana Zimmermann
}

Facultad de Humanidades y Ciencias, UNL

Desde el 29 de abril de 20I4, y durante IO días, se presentó la muestra de fotografías "Agua de Nadie», de Darío Traffano, que conmemora la trágica inundación ocurrida en Santa Fe en 2003. El espacio de presentación y exhibición fue la cede del Concejo Municipal, que la declaró de interés junto a la canción «Eulalia» de Julián Ratti y Efraín Colombo.

Debido a su ubicación geográfica, las inundaciones son previstas en la ciudad, en especial en su costa este. En 2003, la crecida del río Salado se sumó al caudal de agua de lluvias ocurridas en el norte de la provincia durante el año anterior, lo que provocó que todo el cordón oeste santafesino, habitado por familias de clase media no acostumbrados a estos eventos naturales, se viera invadido por el agua. Un tercio de la población debió resolver este fenómeno climático sin preparación previa para la emergencia, sin alerta del hecho y sin saber cómo actuar y ayudar. El autor de la muestra es un reconocido fotógrafo santotomesino, Darío Traffano, quien recopiló el material bajo el título homónimo al audiovisual producto de la investigación periodística llevada a cabo por el Fernando Pais. Esta muestra fotográfica sin dudas rememora a la vez que suma contenido al trabajo realizado por Pais a través de su compilación de testimonios, documentos inéditos, notas y entrevistas al hecho por todos conocidos, parte de la historia santafesina reciente, ocurrida hace II años. 


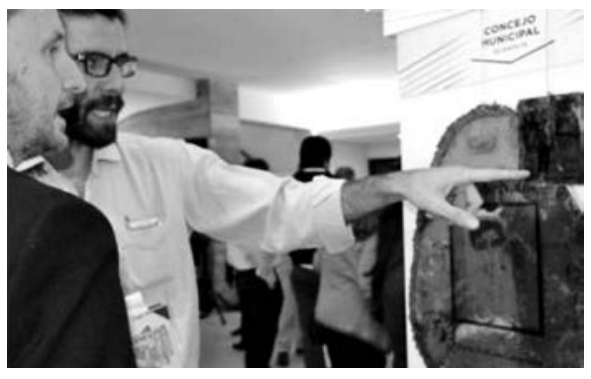

Fotografía de diario Uno, Santa Fe, 29/4/2014.

Extraída de www.unosantafe.com.ar

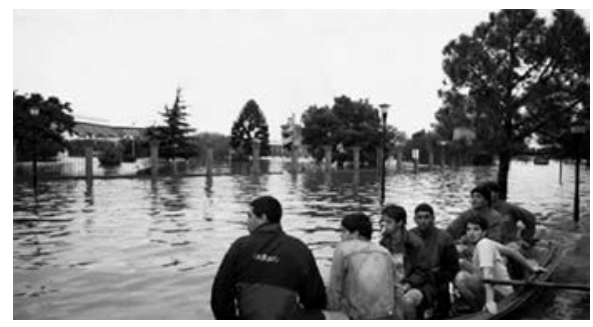

Esta fotografía muestra un detalle del Afiche de promoción de la Muestra Fotográfica "Agua de Nadie", 28/04/2014. Extraída de www.sinmordaza.com.ar
Recorrido por la muestra fotográfica Dispuestas en paneles alargados, a ambos lados, a veces tres y otras, cuatro, las fotografías quedan a la altura de los ojos de los visitantes, evocadas por un título que simplemente denota su contenido. Varios de estos paneles se acomodan en la sala de entrada al Concejo, permitiendo la circulación de los espectadores y del público que recorre las instalaciones por otros motivos.

Los visitantes de la muestra son variados: jóvenes curiosos que se acercan al material inédito y original, adultos que comentan entre sí y evocan lo sucedido, personas solitarias que miran con atención y con gesto serio cada fotografía, en silencio.

Las fotografías tomadas en 2003 evocan situaciones tan emblemáticas como dramáticas, como lo son los botes de rescate, los edificios cubiertos por el agua, las largas colas de gente para recibir alimentos y abrigo, familias con niños evacuando el lugar con el agua a la cintura, y otras tratando de salvar algunos de sus bienes y recuerdos.

El valor documental de la muestra es indiscutible, pero también es significativa la originalidad de la técnica con la que se llevó a cabo: las fotografías están impresas en metales planos y brillantes, que evocan el agua, con bordes irregulares y algunos oxidados, recuperados de aquella época, que rememoran la aspereza del dolor y la injusticia que todavía sienten los santafesinos. Este procedimiento tan curioso como llamativo es un aporte profesional de Traffano para el arte de la fotografía y para la conservación del medio ambiente por el reciclado de los metales y el ahorro de tinta y papel de impresión.

\section{Imágenes y significados de la historia cercana}

Al registro de las fotografías en 2003 le siguió la participación creativa y artística de su autor, que lo ensambló de modo original 
y significativo y logró capturar un nuevo sentido superador de la mera recopilación y puesta en escena, donde el montaje es el principio constructivo que se pone en juego frente a lo visual y a lo percibido, conjugación que resulta un documento que actúa como denuncia, testimonio y construcción social de los hechos.

Lo fundamental de una fotografía es el testimonio de lo que aconteció y la posibilidad para el espectador de informarse, significar y representar los hechos de la realidad evocados, como los de los viajes, las escenas familiares o los autorretratos (Barthes, 1989). En estos casos se posa para la foto, se abandona el cuerpo y se adopta una postura teatral, de personaje. Pero en la muestra de Traffano no vemos simplemente reminiscencias del hecho catastrófico sino que construimos un referente original, de borde, más allá de lo que se representa en ellas y que Barthes llama punctum. La antiteatralidad atraviesa los escenarios fotografiados y concede al espectador espacios para la construcción de sentidos socioculturales originales y emotivos que rebasan los pactados por fotógrafo. Superar la pose (evitar la teatralidad) da lugar al mencionado punctum, cuya antiteatralidad aparece en tanto el tiempo se vuelve y deviene visible tras el acto fotográfico.

El espectador entiende fácilmente la referencia que la imagen transmite o comunica, pero debe tener la astucia de percibir además el significado de la misma. Esta construcción impelida por el fotógrafo lleva al espectador a sentidos socioculturales compartidos algunos, y otros originales, pero también a otros efectos emotivos que genera su lectura.

\section{Intertextos colectivos}

Esta muestra tiene como fin rememorar nuestra historia para reflexionar sobre ella, buscar la verdad y la justicia acerca de los hechos sucedidos, de modo de mantener viva la memoria para que no vuelva a ocurrir. Esto permite la expresividad y la emoción que se reflejan en el montaje de las fotografías y que provoca la muestra, como un relato alternativo al discurso de la historia consensuado por la ciencia. Los registros, estadísticas y documentos históricos de evidencia contundente de los hechos, contrastan con expresiones artísticas y documentales, relatos de historias de vida, todos recursos mnemotécnicos parciales, subjetivos y selectivos. De este modo las conmemoraciones, los monumentos y los diferentes espacios simbólicos para el recuerdo cercano de la historia de una comunidad, aun las tragedias, constituyen una especie de cultura material que a veces desafía a la historia oficial de la cultura dominante.

Del registro fotográfico y fílmico de muchos ciudadanos, sus testimonios en la participación y padecimiento del hecho, surgieron muchos documentos invaluables para la memoria colectiva de su historia. En todas estas muestras, 
como en las fotografías de la muestra de producción, de participación y de de Traffano, o el documental de Pais, recepción de estos testimonios artísticos. desborda la representación visual e in- No dejemos de recorrerlas y de participar volucra necesariamente las condiciones ante la convocatoria.

Bibliografía

- BARTHES, R. (1989). La cámara lúcida. Barcelona: Paidós.

- BRAVI, C. Memorias de la imagen. El uso del archivo audiovisual

en los informes televisivos sobre la inundación de 2003 en Santa

Fe. En www.fhuc.unl.edu.ar/materiales_congresos/cd_historia/

pdf/2-aportes/bravi.pdf (consulta mayo de 2014).

• FRIED, M. (2008). El punctum de RolandBarthes. Murcia:

Cendeac. Murcia Cultural.

• VERÓN, E. (1987). Semiosis social. Barcelona: Gedisa. 